Published in Proceedings of the 1999 IEEE/ASME Joint Railroad Conference, April 1315, 1999, IEEE Catalog Number 99CH36340, ASME RTD Volume 16

\title{
DEVELOPMENT OF A PASSENGER RAIL VEHICLE CRUSH ZONE
}

\author{
Ronald Mayville, Richard Stringfellow, Robert Rancatore \\ Arthur D. Little, Inc. \\ Cambridge, Massachusetts 02140 \\ Kent Johnson \\ Premiere Engineering, Corp. \\ Atlanta, Georgia 30328
}

\begin{abstract}
The use of crush zones in passenger rail vehicles is rapidly growing in the United States and throughout the world. Such crush zones are an important part of the crash energy management philosophy of train occupant protection. The objective of this study was to determine the advantages, disadvantages and issues related to incorporating crush zones at the ends of coach cars for protection in collisions between two trains. The general specifications for the crush zone were selected after consideration of the energy and forces that can be accommodated in such structures. Various designs were considered to meet these requirements and one of these was selected for more detailed development and evaluation. The effort included design layout and nonlinear dynamic finite element analysis to determine crush response.
\end{abstract}

\section{INTRODUCTION}

There is a general trend in the development and construction of passenger rail vehicles throughout the world today known as crash energy management design. The basis of this philosophy is, on the one hand, an explicit acknowledgement that each train collision has associated with it a collision energy that must be dissipated and, secondly, that the greatest safety to train occupants and others is through a deliberate, planned control or management of this energy. Although this philosophy has been used in automobiles for decades, it is only within the last few years that it has had widespread application for trains.

Crash energy management design philosophy generally includes the selection of a collision scenario or scenarios against which protection is to be provided, including the specific desired outcome. A common example is a collision between two like trains, one moving, the other stationary, in which the ends of passengercontaining vehicles are not to crush more than, say, 36 inches $(0.9 \mathrm{~m})$ with a peak vehicle deceleration of less than $6 \mathrm{~g}$ 's. The collision scenario automatically defines the collision energies that must be managed as well as several other key parameters.

A key principal of the crash energy management philosophy is to absorb energy at locations in which there are no occupants. The locations could range from 'sacrificial' baggage cars to the more common approach of absorbing the collision energy in the normally unoccupied ends of several rail cars. This latter approach is sensible when one considers, (a) the importance of maximizing total passenger space for revenuegenerating service, (b) the large energies to be absorbed, especially in train-to-train collisions, and (c) the need to preserve the normally occupied spaces during a collision.

While current orders for trains with crash energy management systems provide tangible evidence of their practicality, there is still a lack of public knowledge about some of the implementation details and weight and cost penalties associated with this new design philosophy. The work described here had as its overall objective a determination of the issues and possibilities of incorporating crush zones at the ends of passenger rail vehicles. The crush zone described here was developed for intercity coach cars but is also applicable for other types of service.

\section{CRUSH ZONE DEVELOPMENT}

\section{Specifications}

The specifications for coach car crush zones include energy absorption capability, maximum crush force, maximum crush distance, and various strength requirements for handling normal operation and for the prevention of override and lateral buckling. The specifications 
are generally derived from the collision scenario against which protection is to be provided and from current knowledge about the conditions of crush and deceleration below which occupants will avoid serious injury. In some cases, the specifications differ for different vehicles in a train consist, as determined by lumped-masstype collision dynamics models. The basis for the specifications used here are described in a separate publication [1], although some explanation is provided here.

For example, we chose a coach car energy absorption goal of $1.5 \times 10^{6} \mathrm{ft}-\mathrm{lbf}(2 \mathrm{MJ})$, based in part on a particular train-to-train collision scenario and on what practice has shown to be feasible. As a reference, new British Rail commuter coach cars are required to absorb $0.75 \times 10^{6} \mathrm{ft}-\mathrm{lbf}(1 \mathrm{MJ})$ of energy at each end [2].

The maximum absorbable energy at a coach car end can be estimated for a particular set of conditions. The absorbed energy can be expressed as the product of the average crush force and the extent of crush:

$E_{a b s}=\left(F_{a v g}\right)\left(l_{c}\right)$.
If we place constraints on the magnitude of the crush force and the extent of crush, we automatically limit the amount of energy that can be absorbed. The maximum crush force is determined by the car body strength, which is generally related to the buff strength of the vehicle, and by the need to limit the decelerations experienced by occupants during a collision.

For example, suppose we wish to limit with certainty the average acceleration to $6 \mathrm{~g}$ 's and the amount of crush to $3 \mathrm{ft}(0.9 \mathrm{~m})$ in a coach car with an $800 \times 10^{3} \mathrm{lbf}(3.6 \mathrm{MN})$ buff strength. Then, for a $100,000 \mathrm{lbm}(45,300 \mathrm{~kg}) \mathrm{car}$, the maximum allowable load is about $600 \times 10^{3} \mathrm{lbf}$ $(2,670 \mathrm{kN})$, which is consistent with the buff strength, and the energy absorption is:

$E_{a b s}=(600,000)(3)=1.8 \times 10^{6} \mathrm{ft}-\mathrm{lbf}(2.44 \mathrm{MJ})$.

Thus, our choice of a $1.5 \times 10^{6} \mathrm{ft}-\mathrm{lbf}(2 \mathrm{MJ})$ goal is below but close to the maximum energy absorption capability based on such considerations.

These and the remaining specifications used for the design of our coach car crush zone are listed in Table 1.

Table 1. Coach Car Crush Zone Specifications Used in this Study

\begin{tabular}{|l|c|}
\hline \multicolumn{1}{|c|}{ Parameter } & Value \\
\hline Energy absorbed & $1.5 \times 10^{6} \mathrm{ft}-\mathrm{lbf}(2 \mathrm{MJ})$ \\
\hline Design crush length & $2-3 \mathrm{ft}(0.6-1 \mathrm{~m})$ \\
\hline Push-back coupler force & $600 \times 10^{3} \mathrm{lbf}(2,670 \mathrm{kN})$ \\
\hline Mean crush force & $700 \times 10^{3} \mathrm{lbf}(3,110 \mathrm{kN})$ \\
\hline Peak crush force & $800 \times 10^{3} \mathrm{lbf}(3,560 \mathrm{kN})$ \\
\hline Vertical strength (during crush) & $200 \times 10^{3} \mathrm{lbf}(890 \mathrm{kN})$ \\
\hline $\begin{array}{l}\text { Permissible lateral deviation of } \\
\text { longitudinal crush load center of action } \\
\text { from vehicle center line }\end{array}$ & \pm 12 inches $(0.3 \mathrm{~m})$ \\
\hline $\begin{array}{l}\text { Permissible vertical deviation of } \\
\text { longitudinal crush load center of action } \\
\text { from underframe }\end{array}$ & +18 inches $(0.5 \mathrm{~m})$ \\
\hline
\end{tabular}

A pushback coupler was specified to ensure direct interaction of underframes in a severe collision and to promote greater distribution of energy absorption among vehicles via a slack effect [1,3]. A pushback force of $600 \times 10^{3} \mathrm{lbf}$ $(2,670 \mathrm{kN})$ appears to be high enough to prevent the pushback mechanism from operating (and thus to prevent the need for repair) for all but the most severe impacts. A peak crush force of $800 \times 10^{3} \mathrm{lbf}(3,560 \mathrm{kN})$ was used with the expectation that decelerations would be lower than the theoretical maximum (because loads are 
applied to both ends of the vehicle at approximately the same time) and that the average crush force would also be lower. Although not common in crash energy management specifications today, we also felt it was important to include a permissible lateral deviation of longitudinal crush load center-ofaction from the vehicle center line. This is because actual train collisions will not occur against a rigid wall and it is likely that there will be some deviation of the line of action between coupled cars. The value of 12 inches $(0.3 \mathrm{~m})$ was selected without technical analysis as a large but reasonable potential deviation. We also used as a specification a permissible vertical deviation of longitudinal crush load center of action from the underframe. Although the crush zone will be designed to prevent override, we felt that the crush zone should nevertheless be capable of absorbing the design energy if loads were applied to the collision posts above the underframe.

\section{Existing/Planned Strategies}

There are now several rail vehicle systems planned or in operation throughout the world that include crash energy management systems.

Some of these are listed in Table 2 together with some of the characteristics of the coach cars. As of this writing, some new purchases of other transit vehicles are also requiring crush zones at the ends of coach cars.

\section{Crush Zone Concept}

The development of a coach car crush zone concept included review of existing systems (see Table 2) and idea generation sessions. We selected concepts that could potentially be adapted to the type of underframe design that is currently found in practice in North America. Such construction consists of a steel underframe to which is attached a stainless steel, steel or aluminum superstructure consisting of light section frames and purlins and skin, all of which participate in load transfer. In particular, we used the Amfleet II intercity coach car as a base from which to make modifications. Three different crush zone concepts were laid out (see [1]) from the various ideas that were generated. From these, only one was selected for detailed consideration.

Figure 1 shows the conceptual drawing and Figure 2 shows the finite element mesh developed to simulate this design; the latter is a one-half model, turned on its side to expose the structure on the underside of the vehicle.

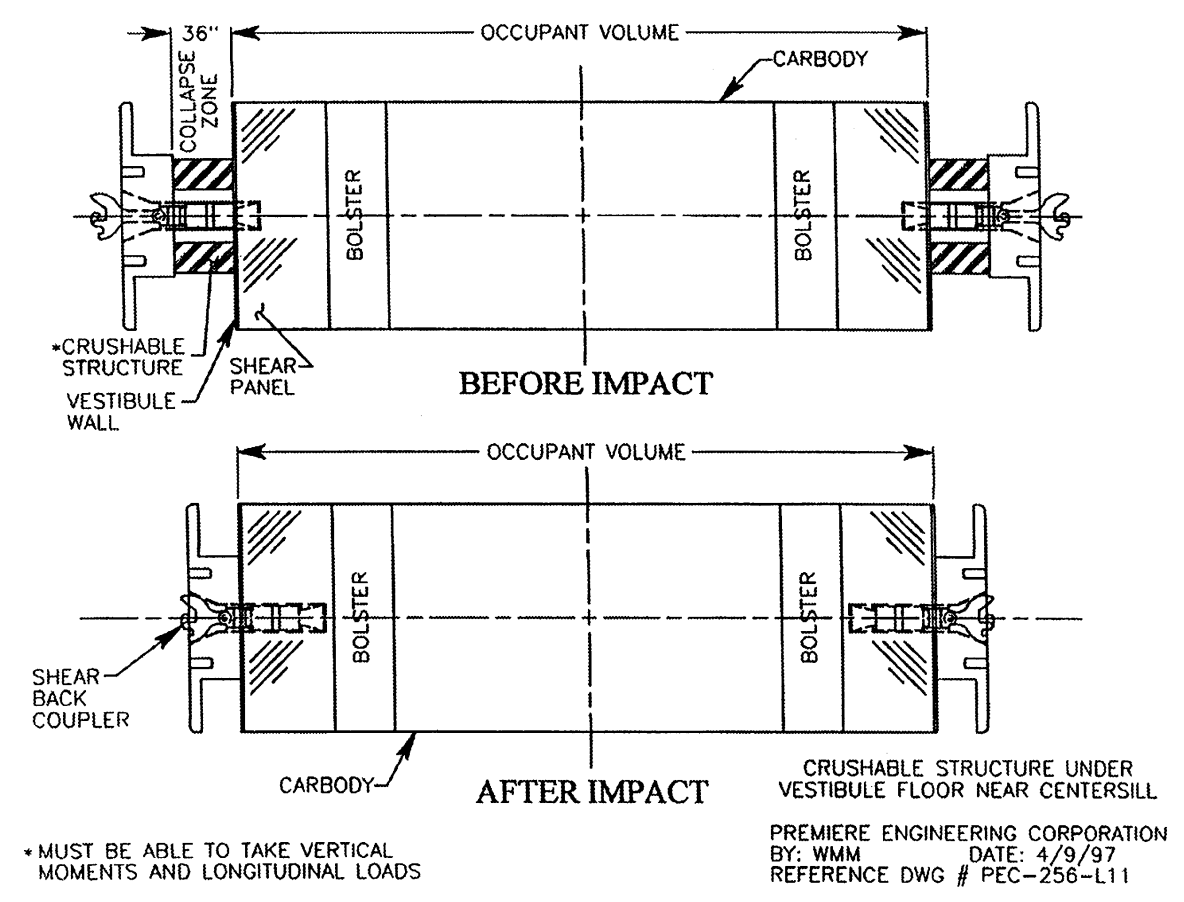

Figure 1. The Concept Layout for the Sliding Sill, Double Crush Element Coach Car Crush Zone 
Table 2. Examples of Crush Zone Characteristics for Existing/Planned Coach Cars

\begin{tabular}{|c|c|c|c|c|c|c|}
\hline Vehicle & Organization & Status & $\begin{array}{c}\text { Design Energy } \\
\text { Absorption }(\mathbf{k J})^{*}\end{array}$ & Material & General Crush Element Characteristics & References \\
\hline $\begin{array}{l}\text { ORE Research } \\
\text { Vehicle }\end{array}$ & British Rail & Built and tested & 1,000 & Steel & $\begin{array}{ll}- & \text { Aluminum honeycomb } \\
\text { - } & \text { Fiber composites }\end{array}$ & 1 \\
\hline $\begin{array}{l}\text { BR Mk1 (Research } \\
\text { Vehicle) }\end{array}$ & British Rail & Built and tested & 1,500 & Steel & $\begin{array}{ll}\text { - } & \text { Steel, large cell honeycomb } \\
\text { - } & \text { Rectangular box sections } \\
\end{array}$ & 2 \\
\hline 465 Networker & Adtranz & Built and tested & 1,000 & Aluminum & $\begin{array}{ll}- & \text { Aluminum honeycomb } \\
\text { - } & \text { Rectangular box sections } \\
\end{array}$ & 3 \\
\hline $\begin{array}{l}\text { TGV 2N Extreme } \\
\text { Trailer }\end{array}$ & SNCF & In service & 3,500 & Aluminum & $\begin{array}{ll}\text { - } & \text { Slotted box beams } \\
\text { - } & \text { Thin-walled prismatic box sections }\end{array}$ & 4 \\
\hline $\begin{array}{l}\text { XTER } \\
\text { Front }\end{array}$ & SNCF & Built and tested & 5,000 & Stainless & $\begin{array}{ll} & \text { Crushable composite in draft gear } \\
\text { - } & \text { Outboard prismatic box sections } \\
\text { - } & \text { Inboard prismatic box sections } \\
\end{array}$ & 6 \\
\hline $\begin{array}{l}\text { American Flyer } \\
\text { Trailer Car } \\
\text { Adjacent to } \\
\text { Power Car } \\
\text { Not adjacent }\end{array}$ & Bombardier & $\begin{array}{l}\text { In design phase; } \\
\text { energy } \\
\text { absorbers tested }\end{array}$ & $\begin{array}{l}5,000 \\
2,000\end{array}$ & Steel & 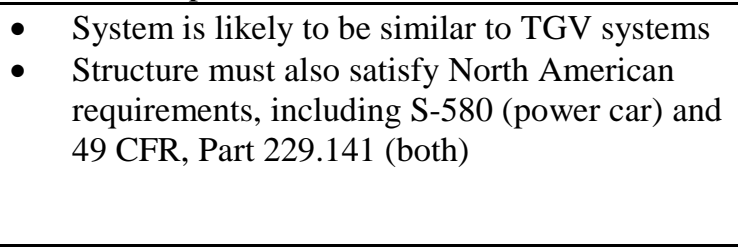 & 7 \\
\hline NJT LRV & Kinky-Sharyo & $\begin{array}{l}\text { In design phase; } \\
\text { energy } \\
\text { absorbers tested }\end{array}$ & 400 & $\begin{array}{l}\text { Steel, with } \\
\text { aluminum } \\
\text { absorbers }\end{array}$ & - $\quad 350 \mathrm{~kJ}$ must be provided by vehicle structure & 8 \\
\hline NYCT & $\begin{array}{l}\text { Bombardier, } \\
\text { Kawasaki }\end{array}$ & Just awarded & 1,000 & Steel & $\begin{array}{l}\text { Energy absorption to be provided by controlled } \\
\text { deformation of the car body }\end{array}$ & 9 \\
\hline
\end{tabular}




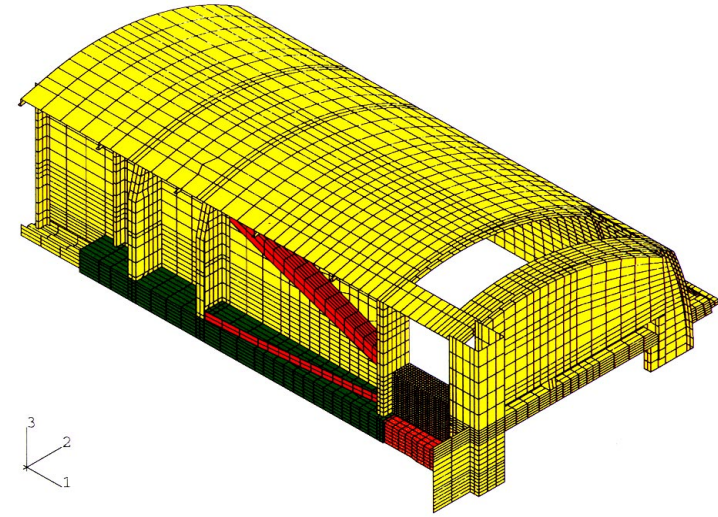

Figure 2. The Finite Element Model Used for the Coach Car Crush Zone

The energy absorption for this concept occurs primarily in two 'double-box' crush elements (see below), one on each side of the center sill. The center sill at the ends of the car is a sliding sill, in which one rectangular box section is permitted to slide into another similar fixed sill after a set of bolts has been fractured in shear from the high collision loads. Thus, the sliding and fixed sills provide a load path for normal operating loads and for bending loads during crush of the absorbers; the energy absorbers only carry load during the crush event. Bending loads are carried through contact between the sliding and fixed sills. The use of sliding sills is a common approach for energy absorption in many US freight cars.

The crush zone includes a pushback coupler that activates when another set of bolts is fractured by shear during the collision. This provides a degree of slack, as mentioned previously, as the coupler pushes back and it enables the anticlimbers and underframes of adjacent vehicles to interact directly during the collision event after the coupler has pushed completely back. Thus, this particular crush zone includes two 'triggers': the first to activate the pushback coupler and the second to activate the crush elements. Though not described here, this crush zone is designed to include ribbed anticlimber elements at each corner to assist in the prevention of override.

Other modifications were needed to obtain satisfactory crush performance for this crush zone. For example, a shear plate was added to the top of the underframe just behind the crush zone, and the sides and roof structure were longitudinally reinforced to prevent any significant local deformation of the occupant volume inboard of the vestibule wall.

Reinforcements were also added on the underside of the underframe (see Figure 2) to support the back of the crush elements and the sides of the fixed sill. These modifications were made to an existing design layout similar to the Amfleet II coach car. Effort to redesign the entire end to optimize weight was beyond the scope of the project.

Thus, the weight added to the vehicle as a result of our modifications is relatively high: about $5,000 \mathrm{lbm}(2270 \mathrm{~kg})$ per vehicle. We believe that detailed optimization of these modifications alone would reduce this value by at least onehalf. Furthermore, design 'from scratch' of a vehicle to include such a crush zone would likely reduce the weight increment even further. The existence of vehicles that contain crush zones whose weights are comparable to strength-based designs supports this assertion.

Finally, it is clear that the doors, if left within the crushable length of the vehicle end, as shown in Figure 2, would be severely deformed as a result of the crush. This would not be acceptable for escape purposes. Therefore, the doors would need to be located inboard of the crush zones, which could reduce potential passenger space for some types of operation.

\section{CRUSH RESPONSE}

We conducted our analysis of the response of the crush zone using the commercially available computer program ABAQUS/Explicit [4]. The models consist almost entirely of shell elements. The material model was represented by a piecewise linear stress-strain curve based on a material with yield and tensile strengths equal to $50 \mathrm{ksi}(345 \mathrm{MPa})$ and $80 \mathrm{ksi}(550 \mathrm{MPa})$,

respectively. In general, simulations consisted of a flat, rigid mass moving at 30-60 mph (48-97 $\mathrm{km} / \mathrm{hr}$ ) colliding with the structure of interest.

\section{Crush Element Response}

The first step in the crush zone evaluation is the analytical verification of the crush element response. As mentioned, we selected a 'doublebox' crush element, in this case made of steel, for the energy absorbing elements. Figure 3 shows its geometry. We kept the geometry of the double-box simple for modeling purposes. In practice, it is advantageous to include features, 


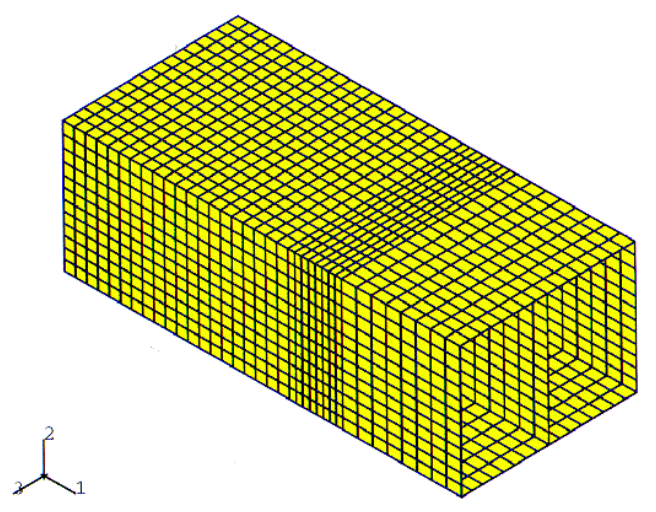

Figure 3. Geometry of the Double Box Energy Absorber Used for the Coach Car Crush Zone: Width $=16$ inches; Height $=8$ inches; Thickness $=0.134$ inches.

such as reinforcements or localized deformations, to reduce the initial collapse load and to ensure that crush occurs in a similar manner for various collision speeds and load combinations. The rear edges of the crush element were fixed against all translations and rotations for the finite element analysis.

Figure 4 shows the energy absorption element load-crush response for a $60 \mathrm{mph}(97 \mathrm{~km} / \mathrm{hr})$ collision with a $50,000 \mathrm{lbm}(26,670 \mathrm{~kg})$ mass. Figure 5 shows an example of the crush pattern from this analysis. There is an initial, high load peak, which corresponds approximately to the plastic buckling load for this section, but overall the crush load is quite uniform until the material begins to compact at about 20-25 inches (0.51$0.64 \mathrm{~m}$ ) of crush. The energy absorbed in one element at a crush of 25 inches $(0.64 \mathrm{~m})$ is $0.77 \times 10^{6} \mathrm{ft}-\mathrm{lbf}(1.0 \mathrm{MJ}$.)

Fracture in this element is not predicted even though the maximum strain, which occurs in a fold at the junction between the center web and the outer surface, reached values close to $90 \%$.

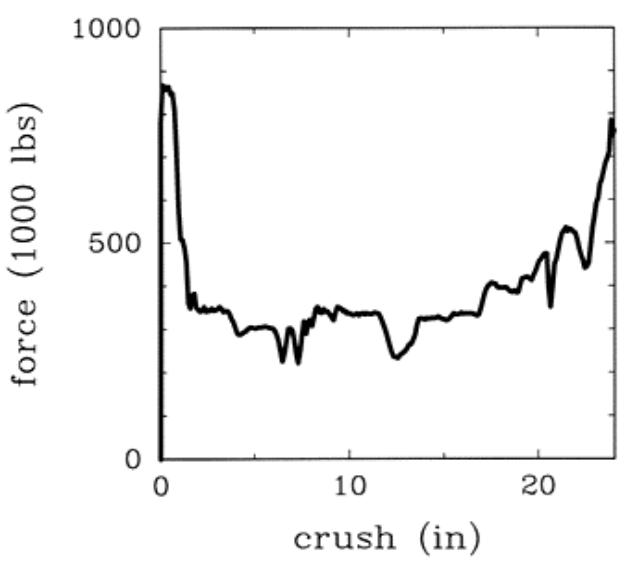

Figure 4. Crush Response of the Double Box Energy Absorption Element

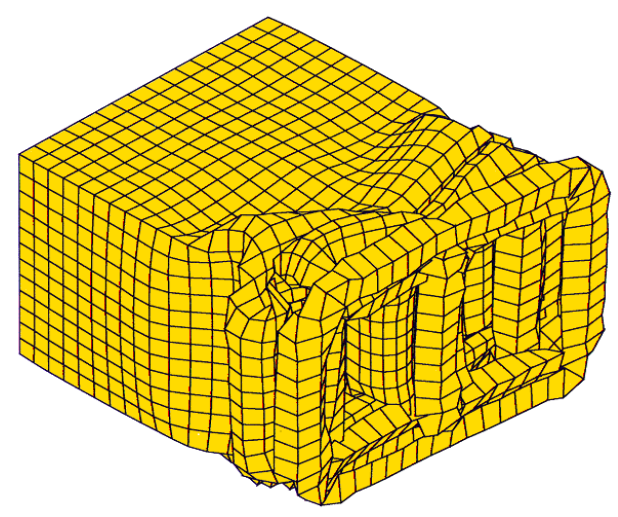

Figure 5. Example of Double B

Element Deformation: Crush $\approx 8$ inches.

\section{Crush Zone Response}

The analysis of the crush zone was carried out with the finite element mesh shown in Figure 2. The longitudinal center plane was thus treated as a plane of symmetry. A set of spring and mass elements were added to the rear of the model to represent the elastic stiffness and the mass of the rest of the vehicle, which had been determined separately from a model of the complete vehicle. Figures 6 and 7 show the deformed mesh and the load-crush response for the crush zone concept for a simulated $60 \mathrm{mph}(97 \mathrm{~km} / \mathrm{hr})$ impact with a flat rigid surface having a mass of $100,000 \mathrm{lbm}$ $(53,340 \mathrm{~kg}$.) The collapse is relatively uniform except for the roof structure, which we did not tailor for the crush zone. The peak crush load in this case, except for the short duration initial peak and the load after the crush zone has compacted, is approximately $700 \times 10^{3} \mathrm{lbf}(3110$ $\mathrm{kN}$.) The energy absorbed at a crush of 26 inches $(0.66 \mathrm{~m})$ is approximately $1.5 \times 10^{6} \mathrm{ft}-\mathrm{lbf}(2 \mathrm{MJ})$ matching the initial requirements. The crush 


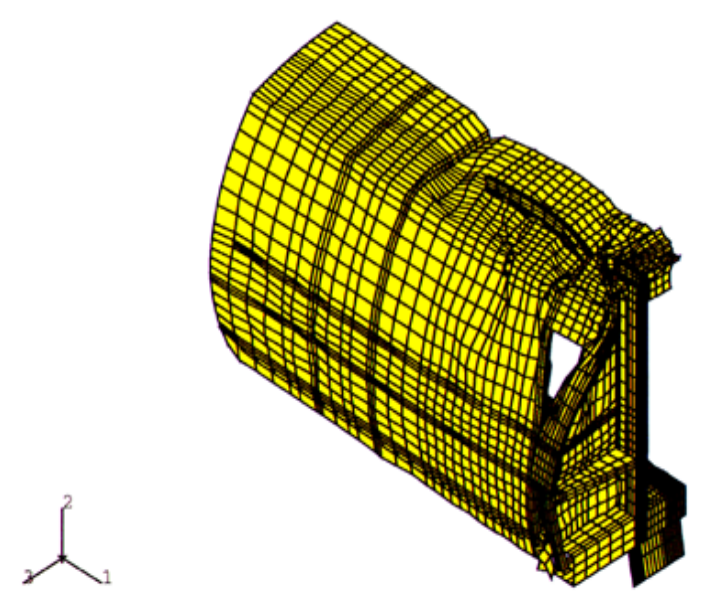

Figure 6. Crush Zone Deformation after Approximately 24 inches of Crush

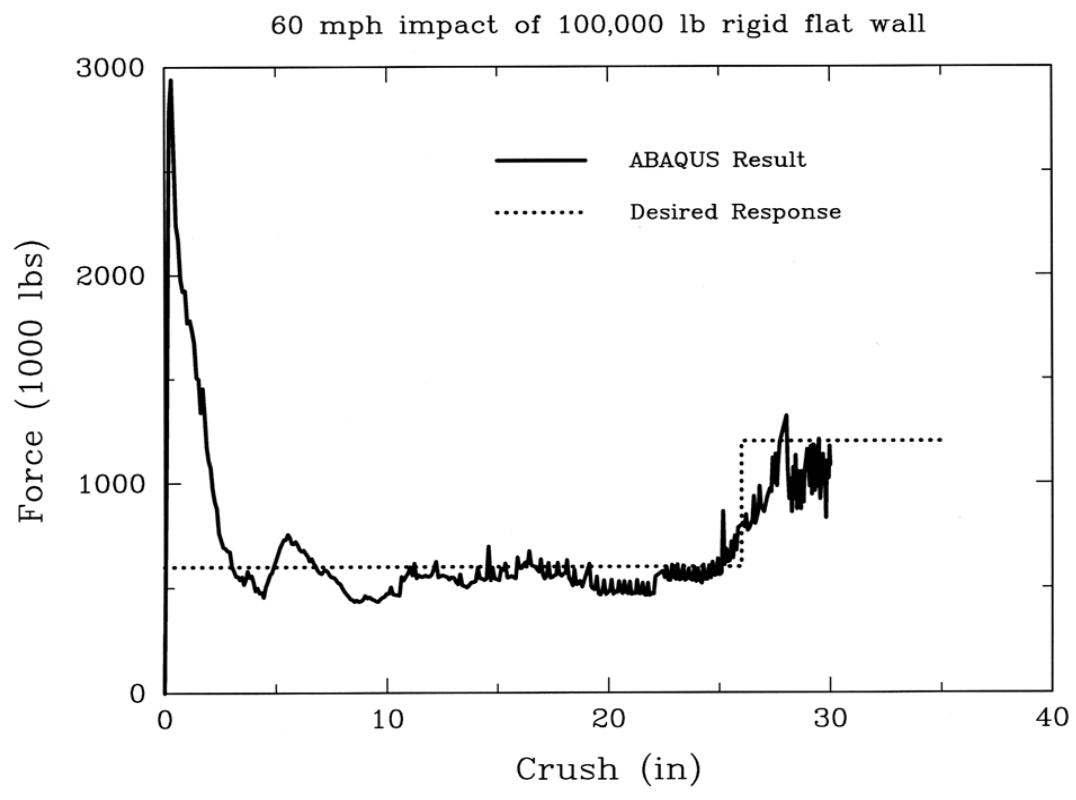

Figure 7. Load-Crush Response of the Coach Car Crush Zone

response for a simulated override loading was quite similar to that shown in Figure 7. However, the model collision post permitted intrusion into the occupied volume, due to excessive post bending. This suggests that stronger collision posts are required.

\section{SUMMARY AND CONCLUSIONS}

This paper presents the conceptual development and the evaluation of a crush zone for intercity passenger rail vehicles for use in crash energy management systems in trains. It illustrates the many considerations needed in engineering such crush zones and offers a specific design that can be used for the type of vehicle underframe that is currently popular in the United States. Our analysis indicates that that a crush zone can be developed in an $800 \times 10^{3} \mathrm{lbf}(3560 \mathrm{kN})$ buff strength rail car whose peak crush load is $700 \times 10^{3} \mathrm{lbf}(3110 \mathrm{kN})$ and which absorbs $1.5 \times 10^{6} \mathrm{ft}-\mathrm{lbf}(2 \mathrm{MJ})$ of energy at each end. Furthermore, these performance specifications 
can be met for a variety of load locations and directions including override loads. The incremental weight associated with this crush zone design is significant. However, we believe that the weight penalty would be substantially lower if vehicle designers included the crush zone in the original design rather than modifying an existing design as we have done.

\section{ACKNOWLEDGMENTS}

This effort was conducted under contract to the Volpe National Transportation Systems Center, as part of the Equipment Safety Research Program sponsored by the Office of Research and Development of the Federal Railroad Administration. The authors would like to thank Mr. David Tyrell, the Volpe Center Technical Monitor, for his helpful insight and direction.

\section{REFERENCES}

1. Mayville, et.al., "Crash Energy Management Design Study: Summary Report," Report to the Volpe National Transportation Systems Center under contract Contract DTRS-5793-D-00026, Cambridge, MA (1999)

2. Structural Requirements of Railway Vehicle Bodies, European Standard (Draft) prEN 00000-0, March 1995.

3. Chatterjee, S. and J.F. Carney III, Controlled Energy Dissipation in Train Collisions, AMD-Vol. 210/BED-Vol. 30, Crashworthiness and Occupant Protection in Transportation Systems, ASME (1995)3545.

4. ABAQUS, Hibbitt, Karlsson \& Sorensen, Pawtucket, RI. 